\section{idenotiune}

Jurnal Kajian Manajemen Dakwah

\title{
Evaluasi Kinerja Manajemen BAZNAS Kota Gorontalo dengan Model CIPP (Context, Input, Process, Product)
}

\author{
Candra Panto ${ }^{1}$, Supandi Rahman ${ }^{2}$ \\ ${ }^{1}$ Fakultas Ilmu Agama Islam Universitas Islam Indonesia \\ ${ }^{2}$ Fakultas Ekonomi dan Bisnis Islam IAIN Sultan Amai Gorontalo \\ Email: supandi@iaingorontalo.ac.id
}

\begin{abstract}
This study aims to determine the extent to which BAZNAS of Gorontalo City manages zakat which will be evaluated using model context, input, process, product (CIPP). This research is a qualitative research. Based on the evaluation of CIPP in BAZNAS Gorontalo city, the evaluation of the context shows that socialization and education in the form of leaflets and electronic media has not been able to increase the trust and understanding of the people of Gorontalo City about the functions and duties of zakat institutions so that the socialization method needs to be updated. In the evaluation of work inputs and the ability of amilinand zakat collection units (UPZ) in every agency in collecting zakat is still very low because it has not applied fundraising techniques. While irthe evaluation of the process of implementation of collection, distribution, and reporting, has not run optimally because there is no good coordination between amilin
\end{abstract}

Keywords: Managemen, evaluation, CIPP Model

\begin{abstract}
Abstrak: Penelitian ini bertujuan mengetahui sejauh mana manajemen BAZNAS Kota Gorontalo dalam mengelola zakat yang kemudian di evaluasi dengan menggunakan model context, input, process, product (CIPP). Penelitian ini termasuk penelitian kualitatif. Hasil penelitian menunjukkan bahwa sosialisasi dan edukasi dalam bentuk selembaran dan media elektronik belum mampu meningkatkan kepercayaan dan pemahaman masyarakat Kota Gorontalo tentang fungsi dan tugas lembaga zakat sehingganya cara melakaukan sosialisasi perlu diperbaharui kembali. Dalam evaluasi input kinerja dan kemampuan para amilin serta Unit Pengumpul Zakat (UPZ) disetiap instansi dalam menghimpun zakat masih sangat rendah karena belum menerapkan tehnik fundraising. Sedangkan dalam evaluasi proses pelaksanaan penghimpunan, pendistribusian, dan pelaporan belum berjalan secara optimal karena tidak adanya koordinasi yang baik antara para amilin.
\end{abstract}

Kata Kunci: Manajemen, evaluasi, model CIPP.

\section{Pendahuluan}

Kata Zakat berasal dari kata zaka yang merupakan isim masdar, yang secara etimologis mempunyai beberapa arti yaitu suci, tumbuh, berkah, terpuji, dan berkembang. Adapun secara terminologis zakat adalah sejumlah harta tertentu yang diwajibkan Allah diserahkan kepada orang-orang yang berhak menerimanya (Mardani, 2012). Selain sebagai ritual ibadah yang diwajibkan agama Islam, zakat merupakan instrument penting dalam pengentasan kemiskinan dan meningkatkan kesejahteraan (Rahman, 2020). Berangkat dari hal tersebut pengelolaan dana zakat harus terus disempurnakan agar pelaksanaan zakat lebih berdaya guna dan dapat dipertanggungjawabkan. Islam menjadikan instrumen zakat untuk 
memastikan keseimbangan pendapatan di masyarakat. Hal ini mengingatkan tidak semua orang mampu bergelut dalam kancah ekonomi. Maka zakat merupakan sumber dana yang potensial untuk mengentaskan kemiskinan (Sudewo, 2004). Jonathan Benthall (1999) dalam studinya menyebutkan bahwa zakat sebagai ibadah finansial (financial worship). Sedangkan sarjana lain seperti Hilman Latief (2014) dan Amelia Fauzia (2017) memasukkan zakat ke dalam istilah filantropi Islam.

Pada akhir dekade 90-an, tepatnya pada tahun 1999, pengelolaan zakat mulai memasuki level negara, setelah sebelumnya hanya berkutat pada tataran masyarakat (Artis, 2019). Indonesia sendiri mempunyai peraturan dalam pengelolaan zakat secara struktural melalaui Undang-undang No. 38 tahun 1999 tentang Pengelolaan Zakat dengan Keputusan Menteri Agama (KMA) No.581 tahun 1999 tentang pelaksanaan Undang-undang No.38 1999 dan Keputusan Direktur Jenderal Bimbingan Masyarakat Islam dan Urusan Haji No. D/291 tahun 2000 tentang Pedoman Teknis Pengelolaan Zakat. Meskipun harus diakui bahwa dalam peraturan-peraturan tersebut masih banyak kekurangan yang sangat mendasar, misalnya tidak ada sanksi bagi muzakki yang melalaikan kewajibannya, tetapi Undang-undang tersebut telah mendorong upaya pembentukan lembaga pengelola zakat yang amanah, kuat dan dipercaya oleh masyarakat. Undang-undang No.38 tahun1999 kemudian diganti dengan UU No. 23 Tahun 2011 tentang pengelolaan zakat, latar belakang penggantian ini adalah bahwa Undangundang Nomor 38 Tahun 1999 tentang pengelolaan zakat dinilai sudah tidak sesuai lagi dengan perkembangan kebutuhan hukum dalam masyarakat sehingga perlu diganti. Pengelolaan zakat yang diatur dalam Undang-undang No.23 Tahun 2011 meliputi kegiatan perencanaan, pengumpulan, pendistribusian, dan pendayagunaan (Aflah \& Tajang, 2006).

Beranjak dari permasalahan inilah, penelitian tentang manajemen kelembagaan amil zakat khususnya di Kota Gorontalo dengan model context, input, process, product (CIPP) sangat diperlukan. Studi-studi terdahulu yang membahas tentang zakat kurang memberikan perhatian pada analisis CIPP. Sebagai contohnya, studi yang dilakukan oleh Imron Rosidi dan Maswan Amin (2019) membahas tentang upaya yang dilakukan BAZNAS Kab. Kepulauan Meranti dalam mendorong kesadaran masyarakat untuk membayar zakat. Temuannya menunjukkan bahwa lemahnya kesadaran masyarakat dalam membayar zakat disebabkan gagalnya lembaga zakat semi-modern seperti BAZNAS dalam menegosiasikan kesadaran religius seperti membayar zakat dengan elemen-elemen modernitas. Berbeda dengan Imron Rosidi dan Maswan Amin, studi yang dilakukan oleh Rama Wijaya Kesuma Wardhani (2018) menunjukkan bahwa keberhasilan BAZNAS, utamanya di Jawa Barat, dalam mengumpulkan dana zakat didorong oleh kemampuan mereka melakukan manajemen komunikasi dengan masyarakat, keterampilan komunikasi antar pengurus, dan membangun jaringan komunikasi kemitraan antar lembaga publik.

Tulisan ini memiliki signifikansi yang berbeda. Tulisan ini mengkaji tentang manajemen zakat yang dilakukan BAZNAS di Kota Gorontalo yang meliputi seperti apa kinerja mereka, program dan strategi pengelolaan apa yang telah dilakukan organisasi pengelola zakat di daerah tersebut yang mencakup upaya perencanaan, pengorganisasian, pelaksanaan program, penghimpunan dan penyaluran dana zakat, serta pengawasan pengelolaan zakat. Untuk mengetahui beberapa hal tersebut, tulisan ini menggunakan sistem 
evaluasi context, input, process, product (CIPP). Sistem evaluasi CIPP ini mencakup kelembagaan filantropi sehingga dapat ditemukan akar persoalan yang menjadi faktor masih jauhnya angka realisasi dengan potensi zakat yang ada sekaligus diberikan konsep tawaran solusi atas permasalahan tersebut.

\section{Metode}

Penelitian ini menggunakan model evaluasi CIPP (Context, Input, Proces, Product), dengan metode penelitian kualitatif, yaitu dalam melakukan suatu evaluasi peneliti menjaring dan menggunakan data kualitatif dengan ciri dalam bentuk narasi, rinci, penelitian mendalamdan melukiskan pengalaman langsung. Penelitian kualitatif juga memiliki asumsiasumsi filosofis, strategi-strategi penelitian, dan metode-metode pengumpulan, analisis, dan interpretasi data yang beragam (Creswell, 2014). Dalam penelitian ini, peneliti (evaluator) merupakan instrument utama dalam menjaring data. Agar peneliti dapat menjaring data dengan teliti dengan lengkap, peneliti menjalankan empat elemen yang harus dipenuhi oleh seorang evaluator, yaitu: Pertama, peneliti berada sedekat mungkin dari orang dan situasi yang sedang diteliti agar dapat memahami dan mendalami rincian apa yang sedang terjadi. Kedua, peneliti menangkap fakta-fakta. Ketiga, data berisi sebagian besar daskripsi, aktivitas, dan interaksi. Keempat, data terdiri dari kutipan langsung dari orang, meliputi apa yang mereka ucapkan dan apa yang mereka tulis (Wirawan, 2011).

\section{Hasil dan Pembahasan}

Manajemen mempunyai arti kata to manage yang memiliki persamaan dengan kata to hand (mengurus) atau to control (memeriksa), to guide (memimpin atau membimbing), jika dilihat dari asal muasal kata dari manajemen sendiri berarti manajemen mempunyai arti pengurusan, pengendalian, memimpin atau membimbing (Effendi, 1986). Sedangkan menurut Zasri M. Ali (2008) manajemen secara umum adalah pengelolaan suatu pekerjaan untuk memperoleh hasil dalam rangka pencapaian tujuan yang telah ditentukan dengan cara menggerakkan orang-orang lain untuk bekerja.

Dari beberapa pengertian manajemen di atas, dapat disimpulkan bahwa manajemen mempunyai keterkaitan dengan usaha untuk mendapatkan hasil tertentu dengan memanfaatkan dan mendayagunakan sumber-sumber daya yang tersedia dalam suatu kegiatan dengan cara yang semaksimal mungkin. Manajemen pada umumnya digunakan untuk suatu organisasi dan juga dalam hubungan usaha suatu pekerjaan secara berkelompok, walaupun sebenarnya manajemen bisa juga dapat ditetapkan terhadap usaha-usaha dalam pekerjaan secarai individu walaupun bekerja secara individu manajemen tetap dibutuhkan untuk mengorganisir semua pekerjaan yang akan dilakukan maupun telah dilakukan. Manajemen adalah proses untuk mencapai suatu hasil yang baik dengan tujuan yang baik pula dengan mekanisme tertentu melalui kegiatan yang dilakuan oleh beberapa orang atau kelompok dengan demikian manajer mengadakan koordinasi atas sejumlah aktivitas orang lain yang meliputi perencanaan, penggorganisasian, pergerakan, dan pengendalian (Amirullah \& Budiyono, 2004). 


\section{Manajemen Zakat di Indonesia}

Pengelolaan zakat dan Organisasi Pengelola Zakat (OPZ) pada awalnya diatur dalam Undang-Undang No. 38 tahun 1999, kemudian direvisi untuk menyesuaikan perkembangan dan masyarakat maka Undang-Undang tersebut disempurnakan menjadi Undang-Undang No. 23 Tahun 2011 tentang Pengelolaan Zakat. Dalam Undang-Undang tersebut, yang dimaksud pengelolaan zakat adalah kegiatan perencanaan, pelaksanaan, dan pengoordinasian dalam pengumpulan, pendistribusian, dan pendayagunaan zakat yang bertujuan untuk meningkatkan efektivitas dan efisiensi pelayanan dalam pengelolaan zakat dan meningkatkan manfaat zakat untuk mewujudkan kesejahteraan masyarakat dan penanggulangan kemiskinan. Sedangkan lembaga yang berwenang melakukan tugas pengelolaan zakat, infak dan sedekah disebut dengan Organisasi Pengelola Zakat. UU no. 23 Tahun 2011 menyebutkan bahwa terdapat dua Organisasi Pengelola Zakat yang berwenang melakukan pengelolaan zakat di Indonesia yakni Badan Amil Zakat Nasional (BAZNAS) dan Lembaga Amil Zakat (LAZ).

Badan Amil Zakat Nasional (BAZNAS) adalah Organisasi Pengelola Zakat yang dibentuk oleh pemerintah. BAZNAS tersebar hampir disetiap tingkatan daerah baik tingkat pusat, provinsi dan kabupaten/kota.BAZNAS berwenang melakukan tugas pengelolaan zakat secara nasional BAZNAS merupakan lembaga pemerintah nonstruktural yang bersifat mandiri dan bertanggungjawab kepada Presiden melalui Menteri. Fungsi BAZNAS adalah menyelenggarakan perencanaan, pelaksanaan, pengendalian dalam pengumpulan, pendistribusian dan pendayagunaan BAZNAS melaporkan hasil pelaksanaan tugasnya secara tertulis kepada Presiden melalui Menteri dan kepada Dewan Perwakilan Rakyat Republik Indonesia.Dalam pendayagunaan zakat, zakat diatur dalam mekanisme perencanaan yang tidak menyimpang dari peraturan pengelolaan zakat. Zakat yang didapatkan dari muzakki dikelola oleh BAZNAS dan LAZ untuk kegiatan bersifat konsumtif dan produktif. Mekanisme pendayagunaan zakat tersebut yaitu Pasal 27 UU. No. 23 Tahun 2011; (1) Zakat dapat didayagunakan untuk usaha produktif dalam rangka penanganan fakir miskin dan peningkatan kualitas umat. (2) Pendayagunaan zakat untuk usaha produktif sebagaimana dimaksud pada ayat (1) dilakukan apabila kebutuhan dasar mustahik terpenuhi.

Prioritas utama dalam pendayagunaan zakat adalah pemenuhan ke-butuhan dasar mustahik (receiver) seperti pemenuhan sandang, pakaian, papan, pendidikan, keamanan, dan kesehatan. Di dalam aplikasinya sekarang, pengertian mustahik tertuju kepada anak yatim, orang jompo, penyandang cacat, orang yang menuntut ilmu, pondok pesantren, anak terlantar, orang yang terlilit utang, pengungsi yang terlantar, dan korban bencana alam. Intinya pendayagunaan zakat pada bagian ini adalah untuk mensejahterakan dan mengangkat masyarakat dari lembah kemiskinan. Penelitian yang membuktikan tentang hal itu misalnya, Shirazi (1996) mencoba untuk menganalisa dampak zakat dan 'ushr terhadap upaya pengentasan kemiskinan di Pakistan. Dengan menggunakan FGT (Foster, Greer dan Thorbecke) Index, Shirazi menemukan bahwa pada tahun 1990-1991, 38 persen rumah tangga di Pakistan hidup di bawah garis kemiskinan. Namun angka tersebut akan menjadi 38,7 persen jika mekanisme transfer zakat tidak terjadi. Hasil penelitian menyimpulkan bahwa kesenjangan kemiskinan menurun dari 11,2 persen menjadi 8 persen dengan kehadiran mekanisme transfer zakat secara sukarela (Beik, 2009). 


\section{Sistem Evaluasi CIPP (Context, Input, Prosess, Product) dan BAZNAS Kota Gorontalo}

Untuk mengetahui seperti apa kinerja manajemen BAZNAS Kota Gorontalo, maka peneliti meminjam ssstem evaluasi CIPP. Pertama, evaluasi konteks. Evaluasi konteks secara sistematis memberikan informasi yang berguna untuk pihak manajemen dalam membuat keputusan. Artinya evaluasi konteks mengidentifikasi kekuatan dan kelemahan dalam sebuah organisasi atau keputusan yang telah dilakukan tujuannya agar kekuatan itu bisa dimanfaatkan dan kelemahan itu bisa tertutupi melalui evaluasi konteks tersebut. Evaluasi konteks memberitahukan tujuan dan prioritas yang menjadi sasaran organisasi (Michael, 2017).

Hasil evaluasi konteks di BAZNAS Kota Gorontalo tahun 2015-2016 terdapat beberapa permasalahan yaitu kepercayaan, pengetahuan, dan pemahaman masyarakat Kota Gorontalo masih terbilang rendah. Pengetahuan akan kewajiban mengeluarkan zakat sudah diketahui dengan baik oleh masyarakat Kota Gorontalo, akan tetapi pengamalan untuk mengamanahkan hartanya di lembaga resmi seperti BAZNAS masih sangat rendah. Krisis kepercayaan kepada lembaga BAZNAS merupakan salah satu faktor penyebabnya yang dilihat dari evaluasi konteks. Berbicara mengenai krisis kepercayaan maka erat kaitannya dengan transparansi, sementara transparansi merupakan satu faktor kunci untuk menilai baik tidaknya pengelolaan lembaga zakat (Rahman, 2018) Selain itu penggunaan dan pemanfaatan informasi belum dimaksimalkan seperti penggunaan SiMBAZNAS dalam melakukan pendataan kepada para muzakki dan mustahik. Padahal potensi zakat di Kota Gorontalo sudah mulai berkembang terbukti dengan meningkatnya ekonomi masyarakat kelas mngengah ke atas. Zakat dari hasil pertanian seperti jagung juga mendukung berkembangnya potensi zakat di Kota Gorntalo tetapi belum mampu meningkatkan kesejahteraan masyarakat Kota Gorontalo pada umumnya.

Kedua, evaluasi Input. Tahap kedua dari evaluasi model CIPP adalah evaluasi masukan. Evaluasi masukan membantu mengatur keputusan, menentukan sumber-sumber yang ada, alternatif apa yang diambil, apa rencana dan strategi untuk mencapai tujuan, bagaimana prosedur kerja untuk mencapainya. Para pengambil keputusan memakai evaluasi masukan dalam memilih diantara rencana-rencana yang ada, menyusun proposal pendanaan, alokasi sumber-sumber, menempatkan staf, menskejul pekerjaan, menilai rencana-rencana aktivitas dan penganggaran.

Hasil evaluasi input menunjukkan bahwa Peraturan Daerah tentang zakat di Kota Gorontalo secara tertulis sudah dikeluarkan oleh pemerintah setempat akan tetapi pengamalan di dalamnya masih sangat rendah hal ini dibuktikan dengan kurangnya pihak-pihak instansi atau BUMN dan BUMD melakukan pembayaran zakat di BAZNAS Kota Gorontalo, ini membuktikan bahwa Peraturan Daerah yang dilekuarkan oleh pemerintah belum sepenuhnya di jalankan sehingganya peran pemerintah mengenai Peraturan Daerah tentang zakat harus dimaksimalkan dikarenakan pihak BAZNAS Kota Gorontalo tidak bisa berjalan sendiri dalam mengembangkan potensi zakat di Kota Gorontalo sehingganya peran pemerintah sangat di butuhkan. 
Dukungan dari pemerintah termasuk faktor utama pendukung dalam perkembangan zakat di Koa Gorontalo, selain dari pemerintah, dukungan dari para ulama di Kota Gorontalo mempunyai pengaruh yang sama dengan pemerintah dalam memberikan edukasi tentang pentingnya menyalurkan zakat pada lembaga formal Negara. Ceramah atau kajian yang diberikan oleh ustad dan ustdja di setiap penyampaian dakwah merekan setidknya bisa mensosialisasikan dan mengingatkan para jamaah yang hadir tentang fungsi dan manfaat BAZNAS dalam melakukan pengelolaan zakat.

Ketiga, evaluasi proses. Evaluasi proses pada dasarnya memeriksa pelaksanaan rencana yang telah dilakukan. Tujuannya adalah memberikan masukan bagi pengelola atau manajer dan stafnya tentang kesesuaian antara pelaksanaan rencana dan jadwal yang sudah dibuat sebelumnya dan efisiensi penggunaan sumber daya yang ada. Apabila rencana tersebut perlu dimodifikasi atau dikembangkan evaluasi proses memberikan petunjuknya.

Evaluasi proses di BAZNAS Kota Gorontalo dalam melakukan pengelolaan zakat di bidang penghimpunan dibantu oleh Unit Pengumpul Zakat (UPZ) untuk mengumpulkan zakat disetiap instansi atau lembaga terkait. Sedangkan dalam pendistribusiannya BAZNAS Kota Gorontalo dan pendayagunaan sesuai dengan program-program yang telah direncanakan sebelumnya dan proses pendistribusian berjalan sesuai dengan Undang-Undang No. 23 Tahun 2011 Pasal 25. Dalam aspek pendayagunaan BAZNAS Kota Gorontalo memberikan modal kepada mustahik yang mempunyai potensi dibidang kewirausahaan dan melakukan pembinaan dengan memberikan motivasi dan semangat dalam mempertahankan dan mengembangkan usahanya, serta melakukan pemantauan terhadap usaha yang dilakukan.

Prosedur pendistribusian, pendayagunaan sudah dilakukan dengan baik akan tetapi dalam penelitan dan wawancara yang dilakukan peneliti, BAZNAS Kota Gorontalo belum mengamalkan sepenuhnya Pasal 26 tentang pemerataan, keadilan, dan kewilayahan. Tidak meratanya pendistribusian yang dilakukan karena menyesuaikan dengan zakat yang dihimpun, tidak optimalnya penelitian dan pendataan kebenaran para mustahik menyebabkan tumpang tindihnya pembagian kepda mustahik sedangkan dalam pendayagunaan para amilin harus memiliki data yang sangat akurat untuk pemberian dana produktif, memang zakat merupakan hak para mustahik tapi dalam pendistribusian zakat produktif tidak semua mustahik mau dan memiliki kemampuan untuk merubah diri mereka sehingganya BAZNAS Kota Gorontalo perlu melakukan pelatihan kepada para mustahik penerima zakat produktif guna mengasah kemampuan mereka. BAZNAS Kota Gorontalo dapat melakukan pendayagunaan dengan melakukan pengembangan ekonomi, pembinaan SDM khusus para mustahik dan membuka layanan Sosial khusus mustahik.

Keempat, evaluasi produk. Evaluasi produk merupakan penilaian yang dilakukan untuk mengukur keberhasilan dalam pencapaian tujuan yang telah ditetapkan. Data yang dihasilkan akan sangat menentukan apakah program diteruskan, dimodifikasi atau dihentikan. Evaluasi ini berupaya mengidentifikasi dan mengakses keluaran dan manfaat, baik yang direncanakan atau tidak direncanakan baik jangka pendek maupun jangka Panjang.Evaluasi produk bertujuan untuk mengukur, menafsirkan, dan menilai capaian-capaian dalam pelaksanaan kegiatan (Michael, 2017). 
Dalam suatu organisasi ada penilaian yang harus diberikan dengan tujuan untuk menilai apakah organisasi yang dijalankan tersebut berhasil atau tidak. Tujuan penilaian ini tidak bermaksud untuk menjatuhkan atau memberi citra negatif pada masyarakat tentang organisasi yang dijalankan. Penilaian dalam bentuk evaluasi produk ini bertujuan membangun, memperbaharui program-program kerja agar lebih baik dan bermanfaat untuk organisasi itu sendiri dan masyarakat.

Pengelolaan zakat di BAZNAS Kota Gorontalo sudah sesuai dengan peraturan UndangUndang No. 23 Tahun 2011 dan telah mengikuti prosedur Rencana Strategi (RESTRA), Rencana Kegiatan Anggaran Tahunan (RKAT) dan sudah dijalankan seoptimal dan semaksimal mungkin oleh para amilin. BAZNAS Kota Gorntalo wajib mendapatkan apresiasi dari pemerintah dan masyarakat terkait kinerja dalam menjaga dan mendayagunakan harta para muzakki untuk kesejahteraan para mustahik serta merangsang pertumbuhan ekonomi di Gorontalo.

Berdasarkan pembahasan dari evaluasi context dan input di BAZNAS Kota Gorontalo ada beberapa temuan dalam pengelolaan zakat yang harus diperbaharui dan dioptimalkan yaitu: Pertama, Pelayanan untuk para Muzakki. Sosialisasi dan edukasi yang dilakukan oleh BAZNAS Kota Gorontalo sudah memberikan dampak positif yaitu kepercayaan masyarakat pada lembaga zakat tentang fungsi dan tugas lembaga zakat, akan tetapi pelaksanaan untuk berzakat masih jauh dari yang diharapkan dikarenakan sosialisasi yang dilakukan masih bersifat himbauan, belum disertai tindakan untuk mempermudah muzakki untuk berzakat. Hal ini merupakan bukti bahwa sosialisasi yang dilakukan masih bersifat wacana sehingga sebahagian masyarakat belum memberikan kepercayaan penuh pada BAZNAS Kota Gorontalo.

Sosialisasi yang dilakukan tidak hanya sekedar memberitahukan zakat dan kewajibannya akan tetapi memberikan kepuasan dalam pelayanan juga menjadi faktor penting untuk meningkatkan dan mempertahankan kepercayaan masyarakat. Memudahkan para muzakki untuk berzakat di lembaga bisa menambah daya himpun dan mendorong kerjasama dengan para donator. Pelayanan yang dilakukan untuk para muzakki bisa melalui media sosial yang tidak lain untuk sebuah kemudahan. Revolusi teknologi dan informasi menawarkan sejumlah kemudahan bagi masyarakat dari berbagai kalangan. Pemanfaatan teknologi ini sudah banyak digunakan oleh berbagai instansi pemerintahan, institusi swasta, perdagangan, pendidikan, bisnis, dan di berbagai sektor lainnya. tawaran kemudahan ini akan memudahkan setiap pekerjaan dan penyebaran informasi yang disampaikan oleh masingmasing pengelolanya (Husna, 2020). Aplikasi yang bisa digunakan BAZNAS berupa Facebook, Whatsapp, Instagram atau media sosial lainnya untuk memberitahukan haul dan nishab zakat para muzakki sedangkan untuk pembayaran zakat para amilin bisa melakukan penjemputan sekaligus pendataan terhadap para muzakki.

Kedua, Penghimpunan di Instansi. Penghimpuna dana zakat di BAZNAS Kota Gorontalo telah dibantu oleh Unit Pengumpul Zakat (UPZ) di setiap instansi dan lembaga. Selain UPZ, BAZNAS Kota Gorontalo juga masih melakukan sosialisasi di setiap BUMN dan BUMD dan menghitung zakat yang wajib mereka keluarkan. Penghimpunnan yang telah dilakukan oleh BAZNAS Kota Gorontalo dalam temuan penelitian dinilai belum efektif, 
secara keseluruhan dari UPZ di masing-masing instansi dan sosialisasi di setiap perusahaan. Tidak efektifnya penghimpunan yang dilakukan oleh UPZ dan BAZNAS Kota Gorontalo, karena cara yang dilakukan dalam penghimpunan masih sama dengan tahun-tahun kemarin tidak adanya ide-ide baru untuk menarik minat para calon muzakki dari instansi atau lembaga untuk menjadi donator.

Penghimpunan yang dipahami hanya sekedar mengambil kewajiban zakat kemudian mendistribusikannya, karena yang diketahui dan dipahami oleh para amilin termasuk UPZ di setiap instansi dan lembaga hanyalah zakat dan kewajibannya sehingga penghimpunan yang dilakukan hanya berputar-putat di wilayah zakat saja sedangkan untuk infak, sedekah dan wakaf sudah menjadi milik lembaga lain. pemahaman seperti ini sudah sangat lama dianut oleh lembaga zakat sejak lembaga ini didirikan, sehingga daya dan cara menghimpun zakat di BAZNAS Kota Gorontalo harus di ubah dari pola pikir dan teknik penghimpuan. Menerapkan tehnik fundraising adalah cara yang paling tepat yang bisa digunakan oleh BAZNAS Kota Gorontalo untuk mnghimpun dana dari masyarakat dan para donatur.

Ketiga, Pendistribusian dan Pendayagunaan Mustahik Produktif. Pendistribusian zakat adalah suatu aktifitas atau kegiatan untuk mengatur sesuai dengan fungsi manajemen dalam upaya menyalurkan dana zakat yang diterima dari muzakki kepada mustahik sehingga tercapainya tujuan organisasi secara efektif (Hamidah \& Romli, 2019). Dalam pendistribusiannya, BAZNAS Kota Gorontalo telah melakukannya dengan benar dengan mengutamakan delapan asnaf, dan menjalankan program-program kerja untuk para mustahik konsumtif yang perlu mendapatkan bantuan langsung dari BAZNAS Kota Gorontalo. Untuk pendistribusian dan pendayagunaan mustahik produktif BAZNAS Kota Gorontalo juga telah merealisasikan melalui pemberian modal dan pembinaan secara berkala agar usaha yang mereka lakukan bisa mensejahterakan perekonomian mereka. Pendistribusian untuk muzakki konsumtif memang seharusnya di utamakan oleh seluruh lembaga zakat baik lembaga yang dibentuk oleh pemerintah maupun masyarakat karena zakat itu sendiri dikhususkan untuk mereka yakni delapan asnaf.

Temuan penelitian yang dilakukan di BAZNAS Kota Gorontalo dalam pendistrubsusiannya adalah kurang meratanya pendistribusian yang dilakukan, karena menyesuaikan dengan dana yang terhimpun. Faktor inilah yang menyebabkan para mustahik belum mendapatkan haknya secara penuh, selain tidak meratanya pendistribusian, pemetaan dan pendataan untuk wilayah para mustahik belum dioptmalkan. BAZNAS Kota Gorontalo mendapatkan informasi tentang keadaan mustahik dari kelurahan disetiap kecamatan setelah itu diadakan verifikasi dengan dinas terkait kemudian menetapkan bantuan dengan persetujaun ketua.

Pendistribusian yang tidak merata, pemetaan, dan pendataan, yang kurang maksimal berpeluang menerima bantuan secara berulang-ulang sehingga sebagaian masyarakat mustahik tidak mendapatkan yang seharusnya menjadi haknya. Pendistribusian juga dilakukan secara langsung oleh para amilin, BAZNAS Kota Gorontalo tidak mengikutsertakan para donator atau pihak-pihak yang telah diajak bekerja sama dalam penghimpunan zakat untuk menambah daya dorong dalam bidang penghimpunan dan 
menambah rasa percaya para donator bahwa harta mereka telah didayagunakn oleh BAZNAS Kota Gorontalo sesuai dengan keinginan mereka.

Temuan lain dalam penelitian ini yakni tentang pendayagunaan untuk mustahik produktif, BAZNAS Kota Gorontalo memberikan modal untuk mereka yang mempunyai kemampuan dalam berwirausaha tetapi tidak memiliki modal yang cukup. BAZNAS Kota Gorontalo menghindari pemberian modal dalam bentuk uang secara langsung, karena pemberian uang secara langsung bisa disalah artikan dan disalah gunakan oleh mustahik produktif, yang dilakukan oleh BAZNAS Kota Gorontalo adalah memberikan modal berupa barang-barang yang diperlukan untuk mengembangkan usaha.

Selain pemberian modal BAZNAS Kota Gorontalo juga melakukan pemantauan, dan pembinaan dengan mengundang para motivator dan para wirausahawan sukses. Pendayagunaan untuk mustahik produktif memang sangat efektif untuk merangsang pertumbuhan ekonomi mereka akan tetapi pelatihan juga perlu diperhatikan. Pelatihan SDM dan tata cara pengelolaan dalam berwirausaha harus diajarkan. kurangnya pemahaman tentang pengelolaan keuangan bisa menjadi faktor penyebab tidak berkembangnya usaha mereka. Pelatihan,dan pembinaan SDM belum diterapkan di BAZNAS Kota Gorontalo yang tujuannya adalah untuk merubah mustahik produktif untuk menjadi muzakki kedepannya.

\section{Simpulan}

Berdasarkan penelitian yang dilakukan terkait manajemen BAZNAS Kota Gorontalo dan pembahasan di bab sebelumnya, dapat diambil beberapa simpulan diantaranya; pertama, Evaluasi dalam dimensi Konteks menunjukkan bahwa tingkat pemahaman masyarakat Kota Gorontalo tentang fungsi dan tugas BAZNAS masih cukup rendah sehingganya metode dalam melakukan sosialisasi dan pemberian edukasi perlu diperbaharaui kembali agar masyarakat Kota Gorontalo tidak hanya paham akan kewajiban zakat tetapi bisa memberikan kepercayaan kepada BAZNAS Kota Gorontalo untuk bisa mendayagunakan harta mereka untuk para mustahik. Kedua, Evaluasi dalam dimensi Input menilai kemampuan para amilin dan Unit Pengumpul Zakat (UPZ) dalam melakukan pengelolaan zakat belum maksimal penyebabnya adalah minimnya pengetahuan dan pemahaman serta koordinasi dalam melakukan pengelolaan zakat sehingganya pelatihan kembali untuk para amilin baik yang berada di BAZNAS maupun di setiap instansi perlu dilakukan. Ketiga, Evaluasi proses sendiri melihat pelaksanaan penghimpunan, pendistribusian, dan pelaporan yang di laksanakan oleh BAZNAS Kota Gorontalo belum secara optimal dilakukan. Bentuk kerjasama dan pendataan untuk muzakki dan mustahik belum dilakukan secara maksimal sehingga penghimpunan dan pendistribusian belum meningkatkan kesejahteraan masyarakat Kota Gorontalo. Keempat, Evaluasi dalam dimensi produk menunjukkan, penghimpunan yang dilakukan oleh Unit Pengumpul Zakat pada setiap instansi masih sangat rendah dan kurangnya kerja sama yang yang terjalin antara para donator dan BAZNAS Kota Gorontalo. Sedangkan dalam pendistribusian dan pendayagunaan untuk mustahik produktif yakni Kota Gorontalo Makmur tidak berjalan secara maksimal karena data dan informasi yang di dapat tidak akuarat yang berberdampak pada kesejahteraan masyarakat Kota Gorontalo. 


\section{Referensi}

Aflah, Kuntarno Noor dan Mohd Nasir Tajang. (2006). Zakat dan Peran Negara. Jakarta: Forum Zakat.

Ali, Zasri M. (2008). Dasar-Dasar Manajemen. Pekanbaru: Suska Press.

Amirullah dan Haris Budiyono. (2004). Pengantar Manajemen, cet. II. Yogyakarta: Graha Ilmu.

Artis. (2019). Strategi Pengelolaan Zakat Berbasis Pemberdayaan Masyarakat Miskin pada Badan Amil Zakat Nasional (Baznas) Kota Pekanbaru. Idarotuna: Jurnal Kajian Manajemen Dakwah, 1(2), 141-148.

Beik, I. S. (2009). Analisis Peran Zakat dalam Mengurangi Mengurangi Kemiskinan: Studi Kasus Dompet Dhuafa Republika. Zakat \& Empowering: Jurnal Pemikiran Dan Gagasan, 2, 45-53.

Benthall, Jonathan. (1999). Financial Worship: The Quranic Injunction to Almsgiving. The Journal of the Royal Anthropological Institute, 5(1), 27-42.

Creswell, J. (2014). Research Design Pendekatan Kualitatif, Kuantitatif, dan mixed. Yogyakarta: Pustaka Pelajar.

Effendi, Mochtar. (1986). Manajemen Suatu Pendekatan Berdasarkan Ajaran Islam. Jakarta: Bhatara Karya Aksara.

Fauzia, Amelia. (2017). Islamic Philanthropy in Indonesia: Modernization, Islamization, and Social Justice. Austrian Journal of South-East Asian Studies, 10(2), 223-236.

Hamidah \& Romli (2019). Pendistribusian Zakat Berbasis Ekonomi pada Dompet Dhuafa Provinsi Riau. Idarotuna: Jurnal Kajian Manajemen Dakwah, 1(2), 149-161.

Husna (2020). Wajah Ekonomi 4.0: Perbankan Syari'ah Digital, Peningkatan Daya Saing dan Strategi Dakwah Islam. Idarotuna: Jurnal Kajian Manajemen Dakwah, 3(1), 59-70.

Latief, Hilman. (2014). Contesting Almsgiving in Post-New Order Indonesia. American Journal of Islamic Social Sciences, 31(1), 16-50.

Mardani. (2012). Fiqh Ekonomi Syariah. Jakarta: Kencana.

Michael., dikutip dari http://www.google.co.id. Michael Scriven/The Intellectual Dimensions of Evaluation Research)

Rahman, Supandi. (2018). Mekanisme Transparansi dan Akuntabilitas Publik pada Baznas Kabupaten Gorontalo. Fakultas Ekonomi, Universitas Islam Indonesia. Yogyakarta. Tesis, diterbitkan pada https://dspace.uii.ac.id/handle/123456789/5693?show=full.

Rahman, Supandi. (2020). Aktivitas Pengelolaan Dana Zakat di Kabupaten Gorontalo. Global Islamic Economy (GIE), 1(1), 78-88.

Rosidi, Imron dan Maswan Amin. (2019). Dakwah Zakat: Menyebarkan Kewajiban Berzakat Di Kalangan Masyarakat Petani Di Kepulauan Meranti. Jurnal Dakwah Risalah, 30(1), 74-90.

Soedewo, Eri. (2004). Manajemen Zakat Tinggalkan 15 Tradisi Terapkan 4 Prinsip. Jakarta: Institute Manajemen Zakat.

Wardhani, Rama Wijaya Kesuma. (2018). Manajemen Komunikasi Badan Amil Zakat Nasional (BAZNAS) Provinsi Jawa Barat. Nalar: Jurnal Peradaban dan Pemikiran Islam, 2(1), 12-21.

Wirawan. (2011). Evaluasi, Teori, Model, Standar, Aplikasi, dan Profesi. Jakarta: Rajawali Pers. 